\title{
Evaluation of Selected Biochemical Indices in Clarias gariepinus Exposed to Aqueous Extract of Nigerian Crude Oil (Bonny Light)
}

\author{
WEGWU, MATTHEW O.; OMEODU, STEPHEN I.
}

Department of Biochemistry, University of Port Harcourt

P.M.B. 5323, Port Harcourt, Nigeria. (e-mail:wevic2000@yahoo.com)

\begin{abstract}
In this study, selected biochemical parameters including the activities of lipid peroxidation in fish exposed to varied percentages of aqueous extract (AE) of Nigerian Crude Oil (Bonny light) were assessed. The total Hydrocarbon and Polycyclic Aromatic Hydrocarbon contents of the AE were $124.1 \mathrm{mg} / \mathrm{l}$ and $16.9 \mathrm{mg} / 1$ respectively. Results of the levels of glucose, total protein, albumin, aspartate aminotransferase and alanine aminotransferase in fish exposed to $10.0 \% \mathrm{AE}$ were $46.2 \mathrm{~m}, 9.18 \mathrm{~g} / \mathrm{dl}, 5.13 \mathrm{~g} / \mathrm{dl}, 62.6 \mathrm{IU} / 1$ and $18.3 \mathrm{IU} / 1$, respectively. Also, the average concentrations of malondialdehyde obtained in Clarias gariepinus exposed to $10 \% \mathrm{AE}$ was $5.84 \mathrm{nmol}$. In general, the concentrations of the selected biochemical indices studied were higher in test fish exposed to $10.0 \% \mathrm{AE}$, followed by those of the lower concentrations. These findings suggest that exposure of Clarias gariepinus to low levels of AE of Nigerian Crude Oil would result in chronic oxidation stress, cellular membrane damage and death of cell. @ JASEM
\end{abstract}

The oil industry has remained the most important source of revenue generation in Nigeria for the past three decades. Oil exploration and exploitation activities are carried out in the southern part of the country with the Niger Delta Area contributing over $90 \%$ of crude oil production (Wegwu, 1999). The occurrence of crude oil spillages in Nigeria is not without deleterious impacts on both the aquatic milieu and terrestrial ecosystems. According to Wegwu and Akaninwor (2006), oil spills are regular features of the oil-producing communities in the Niger Delta area of Nigeria and when these spills occur, either onshore or near shore, it inevitably affects the marine and soil ecosystems. Indeed, these ecosystems are prime factors in agricultural productivity and major livelihood in the oilproducing coastal areas of Nigeria (Osuji and Adesinan, 2005). In these communities, there are numerous crude oil pipelines. In fact, one of the major oil producing companies has ca. $6200 \mathrm{~km}$ of pipelines spread over an area of $31000 \mathrm{~km}^{2}$, with 79 flow stations and two export terminals (NDES, 1999). Burst, arising from rupture of flow lines and / or pipelines; corrosion of flow lines and trunk lines that criss-cross the sensitive ecological terrains of the oil producing communities; hose failure; sabotage and vandalization of the oil installations and production equipment; are among the factors responsible for these spillages (Wegwu and Akaninwo, 2006).

Crude oil varies greatly in composition and consists qualitatively of hydrocarbons and compounds containing oxygen, sulphur, Nitrogen and trace metals. The major hydrocarbon components of crude oil are paraffin, cycloparafffins and aromatic substances containing one or more benzene rings. Polycyclic aromatic hydrocarbons have been detected in Nigerian crude oil (Wegwu, 1999). Various types of Nigerian crude oil are known. However, Bonny light which contains a high percentage of naphthenic hydrocarbons and the medium which has a high specific gravity and more residue (Osuji et. al.,2006), are the major types.

In Nigeria, fish has remained a major source of protein, especially, those living around the coastal areas of the country. There are strong evidence that local fisheries are affected by migrating fish avoiding oiled areas (Powell, 1987). Ezenwa and Ayinla (1994) noted that fish recruitment for the rivers in the Delta Area of Nigeria has been drastically reduced and this factor accounts for the poor catch of fish by the artisanal and pelagic fishermen (Ezenwa and Ayinla, 1994). It has been demonstrated that free radicals are generated from certain pollutants (toxicants), in vivo (Devaki et. al; 2004). The radicals stimulate a sequence of biochemical reactions that lead to the initiation of lipid membrane peroxidation. The ethanol-inducible isoform of the cytochrome P450, CYP2E1, is believed to play an active role in this process (Reinke et. al; 1988). It is our belief that the process of induction of lipid peroxidation by toxicants would provide useful information on the mechanism of oxidative stress in Clarias gariepinus. Therefore, we have attempted in this study, to assess the influence of aqueous extract (AE) of crude oil (Bonny light) on some serum biochemical parameters and the activities of lipid peroxides in Clarias gariepinus.

\section{MATERIALS AND METHODS}

Sample collection: The fish samples used in this study were obtained from a population of fish from African Regional aqua Culture, Aluu, in Rivers State of Nigeria. The Nigerian crude Oil (Bonny light; specific gravity - 0.8343) was obtained from Nigerian National Petroleum cooperation (NNPC), 
Port Harcourt, Nigeria. The Physico Chemical Properties of Bonny light are shown in Table 1.

\begin{tabular}{lc}
$\begin{array}{l}\text { Table 1: Physico-Chemical characteristics of crude oil } \\
\text { (Bonny light). }\end{array}$ \\
\hline Parameter & Value \\
Surface contents & 0.14 \\
Specific gravity & 0.84 \\
American Petroleum Institute (API), $15.5^{\circ} \mathrm{C}$ & 37.0 \\
Viscosity (cSt $\left.{ }^{\mathrm{a}}\right)$ at $25^{\circ} \mathrm{C}$ & 4.09 \\
Wax content $(\%)$ & 3.80 \\
Pour point $\left(-18^{\circ} \mathrm{C}\right)(\%)$ & 23.0 \\
Refractive index & 1.47 \\
\hline \multicolumn{2}{c}{${ }^{\mathrm{c}} \mathrm{CSt}:$ centistokes; } \\
Source, Nigerian National Petroleum Cooperation (NNPC)
\end{tabular}

Preparation of Aqueous extract (AE) of crude oil: The preparation of the aqueous extract of crude oil followed the methods used by Odu et. al; (1985). A 500-ml borosilicate screw-capped conical flask was used to mix $100 \mathrm{ml}$ of crude oil with $300 \mathrm{ml}$ of doubledistilled water. The crude oil/water mixture was shaken for 24 hours at room temperature $\left(25\right.$ to $\left.27^{\circ} \mathrm{C}\right)$ using a Gallenkamp orbital shaker. At the expiration of 24 hours, the mixture was allowed to stand for three hours to obtain clear interphase between oil and water. The mixture was transformed into a glassstoppered separatory funnel and allowed to settle over night. This was to provide enough room for oil droplets in the $\mathrm{AE}$ to settle in the upper layer, while only pure, clear AE were obtained at the lower part of the separatory funnel. Finally, the AE were carefully eluted into dark coloured, screw-capped Winchester bottles and stored in a refrigerator $\left(0\right.$ to $\left.4^{\circ} \mathrm{C}\right)$ until they were required for use.

Chromatographic Analysis of Aqueous Extract (AE) of Crude Oil: The AE of crude oil (Bonny light) was charged to a silica gel column followed by elution of non-polar aliphatic fraction with pentane. The fraction of $\mathrm{AE}$ containing $\mathrm{PAH}$ was eluted using dichloromethane. The fractions were, respectively injected into a Hewlett Packard GC (Model-agilent 6890N; serial number \#US10342047) under standard experimental conditions as specified in the manufacturer's procedural manual. Quantification of the chromatograms was performed using the method of internal standards as reported by Osuji et al. (2006). Chromatographic output was recorded on a Hewlett Packard (Pentium $\left.{ }^{\circledR} 4\right)$ computer.

Toxicity Study: Prior to exposure to AE of crude oil, mature Clarias gariepinus (weighing between 500 to $510 \mathrm{~g}$ ) were acclimatized for 7-days and those that showed signs of weakness and disease were eliminated. During the acclimatization and experimental period that lasted for 30 - days, the test fish were fed with $40 \%$ crude protein (artificially made feed). Into 4-plastic holding tanks with capacities for 50-litres of water were respectively introduced 30 - litres of varied concentrations of AE. Each of the concentrations were in triplicates. The experimentally determined physico-chemical characteristics of dilution water employed in this study is shown in Table 2. Ten (10) test fish were introduced into the various holding tanks containing specific percent AE and the tanks were sealed with nets. At the expiration of the 30-days experimental period, the fish were carefully netted, avoiding stress as much as possible and immediately anaesthetized in a trough containing aerated water and $150 \mathrm{mg} / \mathrm{l}$ lignocaine (Rotex Media - GMBH). When inactivated, fish blood was collected in disposable, 2$\mathrm{ml}$ hypodermic syringe and needle by cardiac puncture. The needle was removed, and the blood gently expressed into a clean, dry, anti-coagulant-free plastic container and mixed. The separation of plasma was performed by centrifugation using MSEMinor 35 model of centrifuge at $5000 \mathrm{~g}$ for 10 minutes. Serum was collected into a clean, dry sample container.

The estimation of total protein in test fish blood was performed using the Biuret method (Garry and Williams, 1977) while serum albumin levels in the samples were determined by the bromocresol green (BCG) binding method (Cheesbrough, 1987). Serum aspartate aminotransferase (E.C. 2.6.1.2) levels in the blood of fish were measured spectrophotometrically as described by Verly (1967).

Fish liver was excised, washed in ice-cold saline, and homogenized at $0.1 \mathrm{~m}$ Tris-HCL buffer $\left(\mathrm{pH} 7.4 ; 4^{\circ} \mathrm{C}\right)$ in a homogenizer at $600 \mathrm{rpm}$ for 4 minutes using mortar and pestle. The fish liver homogenate was used in assaying the activities of lipid peroxidation as described by Hunter et al. (1963) and modified by Gutteridge and Wilkins (1982).

Data Analysis: Data were treated by analysis of variance (ANOVA), and the level of significance was set at $\mathrm{P} \leq 0.05$

\section{RESULTS AND DISCUSSION}

The results of physico-chemical parameters of dilution water employed in this investigation are presented in Table 2. The levels of dissolved heavy metals in the dilution water $(\mathrm{Hg}, \mathrm{Cd}, \mathrm{Cr}, \mathrm{Pb})$ fell below the detection limit of $<1.0 \mu \mathrm{g} / \mathrm{l}$. Other parameters occurred within the acceptable limits for dilution water adopted in Nigeria (FEPA, 1991).

* Corresponding author: Wegwu, Matthew O. 
Table 2: Physico-chemical properties of employed dilution water.

\begin{tabular}{ll}
\hline Parameter & Value $^{\mathrm{d}}$ \\
$\mathrm{Ph}$ & $6.11-6.82$ \\
$\mathrm{Temp} .\left({ }^{\mathrm{C}} \mathrm{c}\right)$ & $26.2-28.4$ \\
Total Hardness $\left(\mathrm{CaCo}_{3}\right)(\mathrm{mg} / \mathrm{l})$ & $18.0-20.5$ \\
Trace metals ${ }^{\mathrm{a}}$ & $\mathrm{BDL}^{\mathrm{b}}$ \\
$\mathrm{DO}^{\mathrm{c}}(\mathrm{mg} / \mathrm{l})$ & $10.0-17.8$ \\
\hline$\left.{ }^{\mathrm{a}) \mathrm{Hg}, \mathrm{Cd}, \mathrm{Cr}, \mathrm{Pb} .}{ }^{\mathrm{b}}{ }^{\mathrm{b}}\right)$ Below detection Limit i.e., $<1.0 \mathrm{mg} / \mathrm{l}$
\end{tabular}

The measured concentrations for the aliphatic hydrocarbons and those of the polycyclic aromatic hydrocarbon (PAH) compounds in the AE of crude oil are shown in Tables 3 and 4. The concentrations of total petroleum hydrocarbon (TPH) and PAH were $124.1 \mathrm{mg} / 1$ and $16.9 \mathrm{mg} / 1$, respectively.

Table 3: Total Petroleum Hydrocarbon Content of Aqueous extract of Nigerian Crude Oil (Bonny Light)

\begin{tabular}{|c|c|}
\hline Hydrocarbon fraction & ${ }^{\mathrm{a}}$ Amount $(\mathrm{mg} / \mathrm{l})$ \\
\hline $\mathrm{n}$ - Pentacosane & $10.29 \pm 1.10$ \\
\hline $\mathrm{n}$ - Hexacosane & $12.49 \pm 4.22$ \\
\hline n - Heptacosane & $9.59 \pm 2.15$ \\
\hline n - Octacosane & $15.78 \pm 4.40$ \\
\hline $\mathrm{n}$ - Nonacosane & $10.79 \pm 5.23$ \\
\hline $\mathrm{n}$ - Triacontane & $11.98 \pm 1.37$ \\
\hline $\mathrm{n}$ - entriacontane & $13.85 \pm 3.11$ \\
\hline $\mathrm{n}$ - Dotriacontane & $20.88 \pm 2.11$ \\
\hline $\mathrm{n}$ - Tritriacontane & $7.73 \pm 2.32$ \\
\hline $\mathrm{n}$ - Tetratriacontane & $10.71 \pm 1.14$ \\
\hline $\mathrm{n}$ - Pentatriacontane & ${ }^{b} \mathrm{ND}$ \\
\hline $\mathrm{n}$ - Hexatriacontane & ND \\
\hline $\mathrm{n}$ - Heptatriacontane & ND \\
\hline $\mathrm{n}$ - Octatriacontane & ND \\
\hline $\mathrm{n}$ - Tetracontane & ND \\
\hline Total & 124.1 \\
\hline
\end{tabular}

Table 4: Concentrations of Polycyclic Aromatic Hydrocarbons (PAH) of Aqueous extract of Nigerian Crude Oil (Bonny Light)

\begin{tabular}{|c|c|}
\hline PAH Component & Amount (mg/l) \\
\hline Naphthalene & $1.35 \pm 1.10$ \\
\hline 2 - methylnaphthalene & ${ }^{\mathrm{a}} \mathrm{ND}$ \\
\hline Acenaphthylene & $0.20 \pm 0.13$ \\
\hline Acenaphthene & ND \\
\hline Fluorene & $4.33 \pm 1.10$ \\
\hline Phenanthrene & ND \\
\hline Anthracene & $2.30 \pm 1.10$ \\
\hline Fluoranthene & ND \\
\hline Pyrene & $3.84 \pm 1.22$ \\
\hline Pyrene dio & 0.31 \\
\hline Benzo (a) Anthracene & $2.84 \pm 1.41$ \\
\hline Chrysene & ND \\
\hline $\begin{array}{l}\text { Benzo (b) } \\
\text { FLuoranthene }\end{array}$ & ND \\
\hline $\begin{array}{l}\text { Benzo } \\
\text { Fluoranthene }\end{array}$ & $1.51 \pm 1.14$ \\
\hline Benzo (a) Pyrene & $0.22 \pm 0.10$ \\
\hline $\begin{array}{l}\text { Dibenzo } \\
\text { Anthracene }\end{array}$ & ND \\
\hline Benzo (g,h,i) Perylene & ND \\
\hline $\begin{array}{l}\text { Indeno } \\
\text { Pyrene }\end{array}$ & ND \\
\hline Total & 16.9 \\
\hline
\end{tabular}

The influence of AE of crude oil on serum glucose, total protein, albumin and liver marker enzymes (AST, ALT) levels in fish serum is shown in Table 5. The analytical results of blood glucose concentrations in test fish exposed to different percentages of $\mathrm{AE}$ of crude oil showed remarkable elevation of blood glucose at higher levels of exposure of fish to the toxicant

Table 5: Concentrations of some biochemical indices in Clarias gariepinus exposed to varied levels of AE of crude oil. Values are means \pm STD for 10 replicates $(n=10)$.

$\begin{array}{cccccc}\% \text { AE } & \begin{array}{c}\text { (Glucose }) \\ \mathrm{mM}\end{array} & \begin{array}{c}\text { Total Protein } \\ (\mathrm{g} / \mathrm{dl})\end{array} & \begin{array}{c}\text { Albumin } \\ (\mathrm{g} / \mathrm{dl})\end{array} & \begin{array}{c}\text { AST } \\ (\mathrm{IU} / 1)^{\mathrm{e}}\end{array} & \begin{array}{c}\text { ALT } \\ (\mathrm{IU} / \mathrm{l})\end{array} \\ 10.0 & \left.46.2 \pm 0.13^{\mathrm{a}}\right) & \left.9.18 \pm 0.13^{\mathrm{a}}\right) & \left.5.13 \pm 0.10^{\mathrm{a}}\right) & \left.62.6 \pm 2.14^{\mathrm{a}}\right) & \left.18.3 \pm 0.22^{\mathrm{a}}\right) \\ 5.00 & 32.3 \pm 2.28)^{\mathrm{b}} & \left.5.61 \pm 0.01^{\mathrm{b}}\right) & \left.3.65 \pm 0.41^{\mathrm{b}}\right) & \left.53.0 \pm 1.95^{\mathrm{b}}\right) & \left.13.6 \pm 0.15^{\mathrm{b}}\right) \\ 1.00 & 33.7 \pm 4.10)^{\mathrm{c}} & \left.49 \pm 0.11^{\mathrm{c}}\right) & \left.2.54 \pm 0.21^{\mathrm{c}}\right) & \left.32.3 \pm 3.23^{\mathrm{c}}\right) & \left.11.0 \pm 0.40^{\mathrm{c}}\right) \\ 0.00 & 15.8 \pm 1.85)^{\mathrm{d}} & \left.4.13 \pm 0.01^{\mathrm{c}}\right) & \left.2.31 \pm 0.11^{\mathrm{c}}\right) & \left.19.3 \pm 1.48^{\mathrm{d}}\right) & \left.11.5 \pm 0.32^{\mathrm{c}}\right)\end{array}$

$\left.{ }^{\mathrm{a}}\right)^{\mathrm{d}}{ }^{\mathrm{d}}$ ) values with different superscripts in the same row are significantly different at the 0.05 level $(\mathrm{p} \leq 0.05)$

e) International Unit/litre.

Total protein concentrations in fish exposed to $10.0 \%$ and $5.00 \%$ AE respectively, showed marked elevation when compared with those exposed to $1.00 \% \mathrm{AE}$ and the control fish $(0.00 \% \mathrm{AE})$. There was no significant difference $(\mathrm{P} \leq 0.05)$ in the total protein concentrations of fish exposed to $1.00 \% \mathrm{AE}$ and control. Similarly, albumin levels in fish exposed to $10.0 \%$ and $5.00 \% \mathrm{AE}$ were much higher than those exposed to $1.00 \% \mathrm{AE}$ and the control samples.

Clarias gariepinus exposed to 10.0, 5.00 and $1.00 \%$ AE showed significant increases in AST concentrations (Table 5). Similarly, ALT concentrations in the serum of test fish exposed to varied levels of AE also demonstrated dependence on 
the level of exposure as higher values were obtained in fish exposed to higher percentage of AE.

Increased concentrations of lipid peroxides (expressed as nmol Malondialdehyde formed $/ \mathrm{mg}$ tissue) (Table 6) were obtained in fish exposed to AE of crude oil. Results showed significant increases in malondialdehyde (MDA) levels corresponding to the $\mathrm{AE}$ concentrations in the holding tanks.

Table 6: Activities of lipid peroxidation in fish exposed to varied concentrations of AE of crude oil.

\begin{tabular}{lcc}
\hline$\% \mathrm{AE}$ & MDA (nmol MDA & formed/mg net tissue MDA) \\
10.0 & $5.84 \pm 1.28^{\mathrm{a}}$ \\
5.00 & $3.71 \pm 2.14^{\mathrm{b}}$ \\
1.00 & $2.88 \pm 1.77^{\mathrm{c}}$ \\
0.00 & $2.04 \pm 1.15^{\mathrm{c}}$ \\
\hline
\end{tabular}

Values with different superscript letters $(a, b, c)$ in the same row are significantly different at the 0.05 level $(\mathrm{P} \leq 0.05)$

The toxicity of Petroleum hydrocarbons to marine organisms; including its carcinogenicity to consumers of marine products, has been reported (Idoniboye and Andy, 1987). Similarly, the presence of PAH in the tissues of fish exposed to crude oil pollution is well documented (Dede, 1998). PAHs are activated to highly reactive epoxides by cytochrome P450containing enzyme systems. These epoxides react spontaneously with DNA bases, causing point mutations (Gerhard and Williams, 1998). In fact, some PAHs have been shown to have genotoxic effects in vivo in rodents and in vitro in mammalian (including human) cell lines and prokaryotes. The presence of petroleum hydrocarbons and PAH in the AE of crude oil (present study) suggest that the source of these hydrocarbons in the fish studied, including those reported by other workers (Dede, 1998)' would be from the water-soluble fractions (i.e. A.E) of crude oil.

It has been shown that low glucose levels in fish would result in inanition and too high levels are an indication of acute or chronic oxidation stress (Heat and Pritchard, 1965). Blood glucose levels of test fish exposed to various concentrations of $\mathrm{AE}$ of crude oil (Table 5), were higher than those of the control. Heat and Pritchard (1965) demonstrated hyperglycemia in bluegill, Lepomis macrochirius subjected to shortterm hypoxia and correlated the increase in blood glucose with a decrease in liver glycogen. The high levels of blood glucose obtained in the exposed fish suggest that Clarias gariepinus were under severe stress during the period of exposure. It is possible that the heinous effects of $\mathrm{AE}$ of crude oil may have negatively affected the biochemical apparatus that is responsible for the balance in body glucose.

Too low plasma total protein in test fish indicate infectious disease, kidney damage and nutritional imbalance and too high value indicate haemoconcentration and impaired water balance (Garry and Williams, 1977). Serum total protein and albumin levels are accepted biochemically as indicators of nutritional status of an organism. The high levels of total protein and albumin obtained in fish exposed to varied levels of $\mathrm{AE}$ of crude oil are indicative of impairment of water balance and haemoconcentration, arising from the poisonous constituents of Bonny light.

As elicited by the elevation in the levels of liver marker enzymes (AST and ALT), exposure of test fish to AE resulted in a significant hepatic damage. Obviously, the elevated levels of these serum enzymes are a direct reflection of alterations in the hepatic structural integrity. ALT and AST levels obtained in this study corroborates those of other workers who reported elevated concentrations in the serum contents of hepatic enzymes in rats exposed to toxic substances such as carbon tetrachloride $\left(\mathrm{CCL}_{4}\right)$ (Patrick-Iwuanyanwu and Wegwu, 2008). These enzymes are located in the cell cytoplasm and are emptied into the circulation once the cellular membrane is damaged (Lin et. al; 2002). In particular, the elevation of ALT is indicative of liver damage.

MDA is a product of lipid peroxidation (Devaki, 2004). An increase in the liver MDA levels is an indication of elevated levels of lipid peroxidation (Patrick-Iwuanyanwu et. al; 2007). Extensive lipid peroxidation leads to disorganization of membrane by peroxidation of unsaturated fatty acids. Under such condition, the ratio of polyunsaturated to other fatty acids is altered. The obvious consequence is a decrease in the membrane fluidity and the death of cell.

Conclusion: High serum levels of glucose, total protein and albumin were recorded in test fish exposed to varied percentages of $\mathrm{AE}$ of crude oil. Similarly, elevated levels of AST, ALT and MDA were obtained in test fish exposed to AE. The elevated levels of the biochemical parameters in this study indicate that exposure of fish to percentages of AE of crude oil would induce acute or chronic stress in fish. It is also evident from our findings that exposure of test fish to AE would lead to cellular membrane damage, decrease in the membrane fluidity and the death of cell.

\section{REFERENCES}

Cheesbrough, M (1987). Medical Laboratory Manual for tropical countries. $2^{\text {nd }}$ Ed. Butterworth, London. Pp.509-511.

Dede, EB (1998). Toxicity and Marine toxicology. NAFCON World Environment Day. Life on Earth; save the sees proceedings of the 1998 seminar. Pp. 34-39. 
Devaki T; Raghavendran, HRB; Sathivel, A (2004). Hepatoprotective nature of seaweed alcoholic extract on acetaminophen-induced hepatic oxidative stress. J. Health Sci. 50:42-46.

Ezenwa, BI; Ayinla, OA (1994). Conservation strategies for endangered fish breeding and nursery grounds within the coastal wetlands of Nigeria. Aquatic conservation, marine and fresh water ecosystems. Vol. 4, 125-133.

FEPA (Federal Environmental Protection Agency) (1991). National Environmental Protection (Effluent Limitation) Regulations. Nigeria. Pp.2-10.

Gary, AW; Williams, TY (1977). Clinical methods for the assessment of the effects of environmental stress on fish health. Technical papers of the U.S. Fish and Wildlife services. Washington D. C. 1977.

Gerhard, M; Williams, HS (1998). Medical Biochemistry. Mosby, Missouri. P. 662.

Gutteridge, JMC; Wilkins, C (1982). Copper dependent hydroxyl radical damage to ascorbic acid: formation of a thiobarbituric acid reactive products. FEBS lett. 137:327-240.

Heat, AG.; Pritchard, AW (1965). Effects of severe hypoxia on carbohydrate energy stores and metabolism in two species of freshwater fish. Physiol. Zool. 38, 325-334.

Hunter, FE; Gebicki, JM; Hoftstein, PE; Weinstein J; Scolt, A (1963). Swelling analysis of rat liver mitochondria induced by ferrous ions J. Biol. Chem. 238:828-835.

Idoniboye, BE; Andy AJ (1987). Effects of oil pollution on aquatic environment. In. Proceedings of 1987 seminar on the petroleum industry and the Nigerian environment. NNPC, Lagos. 311-314.

Lin, SC; Chung, TC; Ueng, TH; Lin, YH; HSU, SH; Chiang, CL; Lin, CC (2002). The hepatoprotective effects of solnum alatam moench on acetaminophen-induced hepatoxicity in mice. AM.J. Uin. Med. 28:105-114.

NDES (Niger Delta Environmental Survey) (1999). Environmental and Socio-Economic Characteristics of the Niger Delta. Revised edn.
Phase-1 Report Environmental Resources Ltd. Lagos pp.3-15.

Odu, CTI; Nwoboshi, IC; Esuruoso, OF (1985). Proceedings of the International Seminar on Petroleum Industry and Nigerian Environment. NNPC, Lagos, p.274-287.

Osuji, CC; Adesiyan, SO (2005). The Isiokpor OilPipeline leakage: Total organic carbon/organic matter contents of affected soils. Chem. Biodiv. 2:1079-1085.

Osuji, LC; Idung, ID; Ojinnaka, CM (2006). Hydrocarbon speciation by Fingerprinting Technique and diagnostic vanadium/Nickel ratio of Mgbede-20 oil-impacted site in the Niger Delta Basin of Nigeria. Environmental forensics. 7:259-265.

Patrick-Iwuanyanwu, KC; Wegwu, MO (2008). Prevention of CCl4-Induced liver damage in rats by Acanthus montanus. Asian J. Biochem. 3(4): 213-220.

Patrick-Iwuanyanwu, KC; Wegwu, MO; Ayalogu, EO (2007). Prevention of $\mathrm{CCL}_{4}$-Induced liver damage by ginger, garlic and vitamin E. Pakistan J. Biol. Sci. 10(4): 617-621.

Powell, CB (1987). Effects of freshwater oil spillages on fish and fisheries. In: proceedings of 1987 seminar on the petroleum industry and the Nigerian environment. NNPC, Lagos, 208-227.

Reinke, LA; Lai,E.K; McCay, PB (1988). Ethanol feeding stimulates trichloromethyl radical formation from $\mathrm{CCL}_{4}$ in liver. Zenobiotics. 18:1311-1318.

Verly, H (1967). Practical clinical biochemistry. $4^{\text {th }}$ ed. Heinemann. London. Pp.891.921.

Wegwu, MO (1999). Seasonal variations of pollutants in some areas of the Niger Delta and their toxicity on some aquatic fauna. Ph.D. thesis. University of Port Harcourt, Nigeria.

Wegwu, MO; Akaninwor, JO (2006). Assessment of heavy metal profile of the New Calabar river and its impart on juvenile clarias gariepinus $\mathrm{J}$. Chem. Biodiv. 3, 79-87.

WHO (World Health Organization) (1998). Environmental Health Criteria 202. Selected non-heterocyclic PAHS. Geneva. 